De Jure: Jurnal Hukum dan Syari'ah

Vol. 10, No. 2, 2018, h. 61-71

ISSN (Print): 2085-1618, ISSN (Online): 2528-1658

DOI: http://dx.doi.org/10.18860/j-fsh.v10i2.4888

Available online at http://ejournal.uin-malang.ac.id/index.php/syariah

\title{
Mediasi Penal Sebagai Alternatif Penyelesaian Perkara Kekerasan Dalam Rumah Tangga
}

\author{
Emy Rosnawati \\ Universitas Muhammadiyah Sidoarjo \\ emyrosnawati@umsida.ac.id \\ Rifqi Ridhlo Pahlevy \\ Universitas Muhammadiyah Sidoarjo \\ qq_levy@umsida.ac.id
}

\author{
Siti Dewi Khotimah \\ Universitas Muhammadiyah Sidoarjo \\ sitidewi@umsida.ac.id \\ Mochamad Tanzil Multazam \\ Universitas Muhammadiyah Sidoarjo \\ tanzilmultazam@umsida.ac.id
}

\section{Abstrak:}

This article aims to describe the process of criminal acts solution for domestic violence by using penal mediation and knowing the constraints in its implementation. The research method used is the juridical sociology with the collection of data through observation, interview, and related research. Qualitative descriptive was used for data analysis. Penal mediation process begins with the agreement of the parties for discussion accompanied by investigator as a mediator so that final decision is reached according to both parties' expectation. Unfortunately, in the implementation, the penal mediation faces some constraints such as no special institution for handling this matter, lack of public trust towards law enforcement, and time limitations. In a nutshell, penal mediation as an alternative dispute resolution in domestic violence is an effective way to support justice.

Artikel ini bertujuan mendeskripsikan proses penyelesaian tindak pidana kekerasan dalam rumah tangga dengan menggunakan mediasi penal dan mengetahui kendala kendala dalam pelaksanaannya. Metode penelitian yang digunakan adalah yuridis sosiologis dengan pengumpulan data melalui observasi, wawancara, dan penelitian terkait kemudian dianalisa secara diskriptif kualitatif. Proses mediasi penal diawali dengan mempertemukan para pihak untuk bermusyawarah dengan didampingi oleh penyidik sebagai mediator sehingga tercapai penyelesaian perkara sesuai keinginan kedua belah pihak. namun dalam prakteknya mediasi penal mengalami kendala antara lain belum adanya lembaga khusus yang menanungi, kurangnya rasa kepercayaan masyarakat terhadap aparat penegak hukum, keterbatasan waktu. Dari penelitian ini dapat disimpulkan bahwa mediasi penal sebagai alternatif penyelesaian sengketa perkara kekerasan dalam rumah tangga lebih efektif daripada sekedar pemidanaan terhadap pelaku.

Kata kunci : kekerasan dalam rumah tangga; mediasi penal; kepolisian 


\section{Pendahuluan}

Kekerasan Dalam Rumah Tangga (KDRT) masih menjadi problem bagi masyarakat di Indonesia. Pasal 1 Undang-Undang Nomor 23 Tahun 2004 tentang Penghapusan Kekerasan dalam Rumah Tangga meyebutkan bahwa setiap perbuatan terhadap seseorang terutama perempuan, yang berakibat timbulnya kesengsaraan atau penderitaan secara fisik, seksual, psikologis, dan/atau penelantaran merupakan bentuk dari kekerasan dalam rumah tangga. ${ }^{1}$ Muladi berpendapat bahwa seorang perempuan yang menjadi korban kekerasan dalam rumah tangga akan menghambat pembangunan, atinya berkurangnya rasa percaya diri perempuan sehingga menghambat perempuan untuk berpartisipasi, berpolitik, serta menganggu pola berfikir dan kesehatan perempuan. ${ }^{2}$

Data Komisi Nasional Perempuan menunjukkan bahwa pada tahun 2015 terjadi 11.207 kasus KDRT ${ }^{3}$ dan 10.205 kasus KDRT pada tahun $2016 .{ }^{4}$ Sedangkan pada tahun 2017 terjadi 9.609 kasus kekerasan di wilayah domestik, dengan 5.167 kasus yang menjadi korban adalah istri. ${ }^{5}$ Data ini belum termasuk para korban yang belum berani untuk melaporkan karena malu jika persoalan pribadinya dibawa ke wilayah publik.

Lahirnya Undang-undang No.23 Tahun 2004 Tentang Penghapusan Kekerasan Dalam Rumah Tangga merupakan wujud jaminan Negara sebagai pencegahan atas kejahatan KDRT.Dengan cara memberikan hukuman pidana kepada pelaku kejahatan sekaligus melindungi korban KDRT.

Ika Kurnia Fitriani menyebutkan bahwa KDRT tidak hanya terjadi karena faktor ekonomi dan pendidikan. Akan tetapi juga disebabkan adanya gangguan psikis dari pelaku. Sebagai upaya penanggulangan KDRT dapat dilakukan pemeriksaan psikis pra nikah. ${ }^{6}$ Hal ini sesuai dengan penelitian Mery Ramadani dan Fitri Yuliani yang menyatakan bahwa adanya riwayat kekerasan yang dialami oleh pelaku dan pola asuh sewaktu kecil memiliki hubungan bermakna dengan perilaku KDRT. ${ }^{7}$ Sebagai wujud komitmen negara melindungi hak para korban, lahirlah Undang-Undang Nomor 23 Tahun 2004 tentang Penghapusan Kekerasan Dalam Rumah Tangga yang disahkan pada tanggal 22 September 2004. Melalui undang-undang ini, berbagai bentuk kekerasan fisik, psikis, ekonomi, maupun seksual yang terjadi di wilayah domestik dikategorikan sebagai

\footnotetext{
${ }^{1}$ Undang-Undang Republik Indonesia Nomor 23 Tahun 2004 Tentang Penghapusan Kekerasan Dalam Rumah Tangga

${ }^{2}$ Hamidah Abdurrachman, "Perlindungan Hukum Terhadap Korban Kekerasan Dalam Rumah Tangga dalam Putusan Pengadilan Negeri Sebagai Implementasi Hak-Hak Korban,” Jurnal Hukum IUS QUIA IUSTUM 17, no. 3 (2010): 475-91.

${ }^{3}$ Komnas Perempuan, "Kekerasan terhadap Perempuan Meluas: Negara Urgen Hadir Hentikan Kekerasan terhadap Perempuan di Ranah Domestik, Komunitas dan Negara: catatan kekerasan terhadap perempuan tahun 2015" (Jakarta: Komnas Perempuan, 2016), 17.

${ }^{4}$ Komnas Perempuan, "Labirin Kekerasan terhadap Perempuan: Dari Gang Rape hingga Femicide, Alarm bagi Negara untuk Bertindak Tepat: catatan kekerasan terhadap perempuan tahun 2016" (Jakarta: Komnas Perempuan, 2017), 21.

5 Komnas Perempuan, "Tergerusnya ruang aman perempuan dalam pusaran politik populisme: catatan kekerasan terhadap perempuan tahun 2017” (Jakarta: Komnas Perempuan, 2018), 14.

${ }^{6}$ Ika Kurnia Fitriani, "Urgensi Pemeriksaan Psikis Pra-Nikah (Studi Pandangan Kepala KUA dan Psikolog Kota Malang)," De Jure: Jurnal Hukum dan Syariah 7, no. 1 (21 Juni 2016): 28, https://doi.org/10.18860/jfsh.v7i1.3506.

${ }^{7}$ Mery Ramadani dan Fitri Yuliani, "Kekerasan dalam rumah tangga (KDRT) sebagai salah satu isu kesehatan masyarakat secara global," Jurnal Kesehatan Masyarakat Andalas 9, no. 2 (2015): 87, http://jurnal.fkm.unand.ac.id/index.php/jkma/article/view/191.
} 
tindak pidana. ${ }^{8}$ Meskipun demikian, tindak pidana KDRT dimasukkan dalam delik aduan. Pelaku KDRT hanya dapat diproses secara hukum jika ada aduan dari korban kepada pihak kepolisian. Hal ini membutuhkan keberanian para korban untuk melapor kepada pihak yang berwajib. Terlebih ada beban psikologis yang harus ditanggung oleh pihak korban. Dalam proses penyidikan pun, pihak kepolisian dinilai belum responsif. Masih ada penyidik yang memandang persoalan KDRT adalah persoalan rumah tangga yang tidak perlu diselesaikan melalui sistem peradilan pidana. ${ }^{9}$ Penyelesaian tindak pidana KDRT di wilayah litigasi cenderung kaku, prosesnya cenderung lama, merenggangkan hubungan kekeluargaan, belum mampu memunculkan efek jera bagi pelaku, serta menyisakan trauma pada diri korban.

Penyelesaian kasus KDRT juga dapat dilakukan melalui upaya non litigasi yaitu mediasi penal. Hal ini sejalan dengan doktrin dalam hukum pidana yang menyatakan bahwa sanksi pidana merupakan ultimum remedium, yang berarti sanksi pidana baru dijatuhkan jika sarana-sarana lain sudah tidak mampu menyelesaikan suatu persoalan. ${ }^{10}$ Pelaksanaan mediasi penal menggunakan paradigma restorative justice. Paradigma ini menekankan keterlibatan pelaku, korban, keluarga dan masyarakat dalam menyelesaikan kasus KDRT. Korban dapat didengar curahan hatinya dan pelaku dapat memperbaiki diri serta bertanggung jawab atas perbuatan yang dilakukan, serta mempertahankan keutuhan keluarga. Meskipun demikian, pelaksanaan mediasi penal menemui beberapa masalah. ${ }^{11}$

Menurut Muhammad Ishar Helmi, aparat penegak hukum melakukan proses mediasi antara pelaku dan korban tidak mengacu pada misi memutus siklus kekerasan dan memberi efek jera pada pelaku. Informasi dari korban acap kali diabaikan dan korban merasa terintimidasi kemudian mencabut laporannya. ${ }^{12}$ Penanganan kasus KDRT melalui mediasi penal telah dilakukan di sejumlah daerah, salah satunya dilakukan di wilayah hukum Kepolisian Resort Kota Sidoarjo. Data perkara menunjukan telah terjadi 67 kasus KDRT antara Mei 2015 sampai Mei 2017. Menariknya sebanyak 59 kasus dapat diselesaikan dengan menggunakan mediasi penal. Berdasarkan persoalan diatas tujuan artikel ini adalah mendeskripsikan pelaksanaan penyelesaian kasus KDRT di wilayah hukum Kepolisian Resort Kota Sidoarjo.

\section{Metode Penelitian}

Penelitian ini termasuk dalam penelitian yuridis empiris dengan pendekatan deskriptif. Data primer diperoleh langsung dari informan melalui proses wawancara semi terstruktur. Sedangkan data sekunder diperoleh dari artikel jurnal, buku, data statistik, laporan penelitian terkait kasus kekerasan dalam rumah tangga. Data sekunder didapatkan melalui teknik dokumentasi. Data yang telah diperoleh dianalisis menggunakan konsep

\footnotetext{
8 Nadir, "Politik hukum pidana dalam upaya penghapusan kekerasan rumah tangga sebagai wujud pengakuan dan perlindungan ham," Al-Ahkam: Jurnal Pemikiran Hukum Islam 5, no. 1 (2010): 159.

9 Nita Savitri, "Kekerasan dalam rumah tangga (KDRT) dan budaya hukum: suatu tinjauan antropologis," Jurnal Harmoni Sosial 2, no. 1 (2007): 27.

${ }^{10}$ Sudaryono, M. Iksan, dan Kuswardani, "Model penyelesaian secara alternatif dalam peradilan pidana (studi khusus terhadap model penyelesaian perkara pidana oleh lembaga kepolisian)," Jurnal Penelitian Humaniora 13, no. 1 (2012): 65.

${ }^{11}$ Hani Barizatul Baroroh, "Mediasi penal sebagai alternatif penyelesaian kekerasan dalam rumah tangga (KDRT)," IN RIGHT:Jurnal Agama dan Hak Azazi Manusia 2, no. 1 (2012): 192-201.

${ }^{12}$ Muhammad Ishar Helmi, "Pengadilan Khusus KDRT 'Implementasi Gagasan Sistem Peradilan Pidana Terpadu Penanganan Kasus-Kasus Kekerasan Terhadap Perempuan (SPPT-PKKTP)," JURNAL CITA HUKUM 2, no. 2 (12 Januari 2014): 319, https://doi.org/10.15408/jch.v1i2.1471.
} 
restorative justice dan mediasi penal. Data yang diperoleh dilakukan pengecekan ulang dan diuji validitasnya menggunakan teknik trianggulasi sumber.

\section{Hasil dan Pembahasan}

\section{Mediasi Penal sebagai Tawaran Baru dalam Penyelesaian Kasus Pidana}

Mediasi merupakan salah satu alternatif penyelesaian sengketa yang berada di luar pengadilan. Secara umum mediasi didefinisikan sebagai alternatif penyelesaian sengketa dengan melibatkan pihak ketiga yang netral untuk mencari solusi yang memuaskan (winwin solution). Mediasi memiliki beberapa kelebihan, antara lain biaya yang dikeluarkan lebih ringan, waktu dan prosedur yang fleksibel, serta mengutamakan kepentingan bersama para pihak. ${ }^{13}$ Mediasi diyakini mampu menyelesaikan masalah secara tuntas dan adil. Kesepakatan yang dihasilkan dirumuskan pihak yang bersengketa dan hasilnya bersifat win-win solution. Konsekuensinya, tidak ada lagi resistensi dari pihak yang lawan. ${ }^{14}$ Berbagai keuntungan yang dihasilkan mediasi, menjadikan metode ini diintegrasikan ke dalam sistem peradilan di Indonesia. Sebagaimana diatur dalam Peraturan Mahkamah Agung Republik Indonesia Nomor 1 Tahun 2016 tentang Prosedur Mediasi. ${ }^{15}$

Mediasi dapat digunakan untuk menyelesaikan berbagai konflik, seperti perkawinan, ${ }^{16}$ pertanahan,${ }^{17}$ medis,${ }^{18}$ suku, ${ }^{19}$ agama hingga perselisihan dalam partai politik. Di kemudian hari, mediasi juga digunakan dalam penyelesaian berbagai tindak pidana. Menurut Barda Nawawi Arief, praktik mediasi penal sering ditemukan dalam kehidupan bermasyarakat. ${ }^{20}$ Misalnya dalam tindak pidana dunia maya atau cyber crime,${ }^{21}$ tindak pidana kekerasan dalam rumah tangga, ${ }^{22}$ tindak pidana lalu lintas, ${ }^{23}$ tindak

13 Erik Sabti Rahmawati, "Implikasi Mediasi Bagi Para Pihak yang Berperkara di Pengadilan Agama Malang," De Jure: Jurnal Hukum dan Syariah 8, no. 1 (Juni 2016): 2, https://doi.org/10.18860/jfsh.v8i1.3725.

${ }^{14}$ Nevey Verida Ariani, “Alternatif penyelesaian sengketa bisnis di luar pengadilan,” Rechtsvinding: Media Pembinaan Hukum Nasional 7, no. 1 (2012): 286.

15 Peraturan Mahkamah Agung Republik Indonesia Nomor 1 Tahun 2016 tentang Prosedur Mediasi di Pengadilan

${ }^{16}$ Ridwan Jamal, "Resolusi Konflik Perkawinan Melalui Mediasi Dalam Perkara Perceraian Di Pengadilan Agama Manado," Jurnal Ilmiah Al-Syir'ah 15, no. 2 (31 Desember 2017): 163, https://doi.org/10.30984/as.v15i2.478.

17 Sri Hajati, Agus Sekarmadji, dan Sri Winarsih, "Model Penyelesaian Sengketa Pertanahan Melalui Mediasi Dalam Mewujudkan Penyelesaian Yang Efisiensi Dan Berkepastian Hukum," Jurnal Dinamika Hukum 14, no. 1 (31 Januari 2014): 47, https://doi.org/10.20884/1.jdh.2014.14.1.275.

${ }^{18}$ Setiati Widihastuti, Sri Hartini, dan Eny Kusdarini, "Mediasi dalam penyelesaian sengketa kesehatan di jogja mediation center,” Socio: Jurnal Ilmu-Ilmu Sosial 14, no. 1 (2017): 25.

19 Amalia Irfani, "Peran Forum Mediasi Dalam Meminimalisir Konflik Di Kalimantan Barat," Al-Hikmah 9, no. 2 (1 Desember 2015): 268, https://doi.org/10.24260/al-hikmah.v9i2.327.

${ }^{20}$ Liliana Tedjosaputro dan Krismiyarsi Krismiyarsi, "Kebijakan Penanggulangan Kejahatan Melalui Mediasi Penal Sebagai Alternatif Penyelesaian Tindak Pidana Kdrt," Jurnal Kriminologi Indonesia 8, no. 1 (25 Juli 2012): 59, http://journal.ui.ac.id/index.php/jki/article/view/1081.

21 Bambang Sukoco, "Pendekatan Restoratif Justice Sebagai Upaya Penyelesaian Cybercrime Dengan Pelaku Anak (Studi Kasus Penyelesaian Tindak Pidana Anak Usia Sekolah)," Law and Justice 1, no. 1 (31 Oktober 2016): 63, https://doi.org/10.23917/laj.v1i1.2859.

${ }^{22}$ I. Ketut Widiarta, Prija Djatmika, dan Bambang Sugiri, "Penyelesaian perkara kdrt melalui mediasi penal pada tingkat penyidikan di polres kapuas," Kumpulan Jurnal Mahasiswa Fakultas Hukum 1, no. 1 (2014): 25, http://hukum.studentjournal.ub.ac.id/index.php/hukum/article/view/482.

${ }^{23}$ Nella Sumika Putri dan I. Tajudin, "Penyelesaian tindak pidana lalu lintas melalui pendekatan restorative justice sebagai dasar penghentian penyidikan dan perwujudan asas keadilan dalam penjatuhan putusan," Padjadjaran Journal of Law 2, no. 1 (27 April 2015): 165, http://jurnal.unpad.ac.id/pjih/article/view/7178. 
pidana yang melibatkan anak sebagai pelaku, ${ }^{24}$ bahkan diusulkan untuk menangani tindak pidana korupsi. ${ }^{25}$

Pelaksanaan mediasi penal merupakan solusi atas kelemahan sistem pemidanaan di Indonesia. Penelitian Badan Pembinaan Hukum Nasional menunjukkan bahwa sistem peradilan pidana memiliki beberapa kelemahan, antara lain: Pertama, adanya proses dehumanisasi pelaku tindak pidana. Pemberian sanksi pidana menjadikan kehidupan pelaku kejahatan tidak lagi produktif di masyarakat. Kedua, adanya kontaminasi antar pelaku tindak pidana. Penjahat kebetulan (accidental offenders), pendatang baru (novices in crime) dirusak melalui pergaulannya dengan penjahat-penjahat kronis di dalam penjara. Ketiga, stigmatisasi pelaku tindak pidana. Sanksi penjara yang diterima pelaku tindak pidana menimbulkan beban psikologis, karena masyarakat telah mengetahui kejahatan yang dilakukannya. ${ }^{26}$

Mediasi penal dilaksanakan berdasarkan paradigma restorative justice. Paradigma ini menghendaki perubahan pola relasi antara pelaku, korban dan negara yang saling berhadapan menjadi pola kooperatif dan integrasi. Restorative justice memberikan pendekatan seimbang terhadap kebutuhan korban, pelaku, dan masyarakat melalui proses pemeliharaan keamanan dan martabat bagi semua pihak. ${ }^{27}$ Bagir Manan sebagaimana dikutip oleh Barda Nawawi Arid menyatakan bahwa restorative justice merupakan satu upaya membangun partisipasi bersama antara pelaku, korban, dan kelompok masyarakat menyelesaikan tindak pidana. Paradigma ini memposisikan pelaku, korban, dan masyarakat sebagai "stakeholders" yang bekerja bersama dan langsung berusaha menemukan penyelesaian yang dipandang adil bagi semua pihak (win-win solutions). Tujuan paradigma restorative justice adalah memperbaiki atau memulihkan (to restore) perbuatan kriminal yang dilakukan oleh pelaku kejahatan dengan tindakan yang bermanfaat bagi pelaku, korban dan lingkungannya yang melibatkan mereka secara langsung (reintegrasi dan rehabilitasi) dalam penyelesaian masalah. ${ }^{28}$

Pelaksanaan mediasi penal lebih menekankan adanya dialog, negosiasi, musyarawarah, sehingga melahirkan kesepakatan yang dapat diterima oleh para pihak. Mediasi penal lebih menekankan pemulihan korban dan membebankan pertanggungjawaban atas kesalahan kepada pelaku kejahatan melalui upaya perbaikan dengan cara mengidentifikasi akar perkara yang kemudian menentukan upaya perbaikan yang seharusnya di perlukan. ${ }^{29}$ Pelaksanaan mediasi penal pada perkara pidana memiliki beberapa tujuan, antara lain: (a) Mengurangi terjadinya penumpukan perkara pada Lembaga Peradilan; (b) Lebih mengedepankan sifat desentralisasi hukum yaitu dengan melibatkan pihak-pihak yang berperkara untuk dipertemukan secara lansung dengan menjamin pemberdayaan para pihak dalam menyelesaikan perkara; (c) Adanya

\footnotetext{
${ }^{24}$ Sumiadi, Laila M. Rasyid, dan Romi Asmara, "Restorative justice hakim terhadap anak yang berkonflik dengan hukum di pengadilan negeri lhokseumawe," Mimbar Hukum 29, no. 1 (2017): 52.

${ }^{25}$ Budi Suhariyanto, "Restorative justice dalam pemidanaan korporasi pelaku korupsi demi optimalisasi pengembalian keuangan negara," Jurnal RechtsVinding: Media Pembinaan Hukum Nasional 5, no. 3 (2016): 436.

${ }^{26}$ M. Taufik Makarao, "Pengkajian hukum tentang penerapan restorative justice dalam penyelesaian tindak pidana yang dilakukan oleh anak-anak" (Jakarta: BPHN Kementerian Hukum dan Hak Asasi Manusia Republik Indonesia, 2013), 26-27.

${ }^{27}$ Kuat Puji Prayitno, "Restorative justice untuk tindak pidana di Indonesia: [ersektif yuridis filosofis dalam penegakan hukum in concreto," Dinamika Hukum 12, no. 3 (2012): 40.

${ }^{28}$ Makarao, "Pengkajian hukum tentang penerapan restorative justice," 8.

29 Yulia Pratiwi, "Peranan advokad dalam menerapkan mediasi penal sebagai alternatif penyelesaian perkara pidana: studi penerapan mediasi penal di wiayah surakarta" (Skripsi, Universitas Jenderal Soedirman, 2013), 40.
} 
perhitungan mengenai kepentingan dan posisi korban sehingga dalam pemecahan perkara KDRT kepentingan korban dapat terakomoditir; (d) Biaya penyelesaian perkara relative murah dengan proses penyelesaian perkara yang relatif cepat; (e) bersifat tertutup dan rahasia; (f) Meminimalisir adanya permainan kotor oleh mafia hukum yang menjadikan biaya menjadi semakin mahal dan lamanya proses penyelesaian perkara pidana di lembaga peradilan. ${ }^{30}$ Tidak jauh berbeda dengan konsep mediasi pada umumnya, pelaksanaan hasil kesepakatan dalam mediasi penal bergantung kepada iktikad baik para pihak. Berdasarkan hal ini, proses mediasi penal harus melibatkan lembaga hukum yang terkait dengan peradilan pidana, seperti Kepolisian, Kajaksaan, maupun institusi peradilan. Hal ini bertujuan agar mediasi penal tetap dapat dikendalikan oleh sistem peradilan pidana, sehingga hasil yang menjadi putuskan dari mediasi penal tetap memiliki kekuatan hukum. ${ }^{31}$

Mediasi penal dapat memberikan rasa keadilan yang memuaskan bagi pihak yang berperkara, Kebijakan mediasi penal sebagai alternatif dalam penyelesaian perkara pidana secara umum dapat diketahui ada beberapa kendala dalam pelaksanaannya, yaitu: (1) Belum adanya lembaga yang menaungi mediasi penal baik dikalangan penegak hukum maupun di masyarakat; (2) Pada sistem peradilan pidana yang dalam proses penyidikannya, apabila dalam penyidikan telah dilakukan penahanan terhadap tersangka, mewajibkan perkara tersebut untuk lanjut sesuai litigasi yang kemudian berproses pada penuntutan dan persidangan. Apabila telah dilakukan penahanan terhadap tersangka maka hakim akan menjatuhkan pidana perjara kepada tersangka. Sehingga tidak dapat terlaksanakannya proses mediasi pada perkara tersebut; (3) Dampak atau kerugian atas kekerasan dalam rumah tangga yang menimbulkan luka berat kepada korban sehingga tidak lagi bisa dimaafkan; (4) Bagi korban kekerasan dalam rumah tangga khususnya perempuan, terkadang tidak mau untuk dilakukan proses mediasi dikarenakan sebelumnya sudah memilki pria idaman lain.Sehingga mempengaruhi korban untuk tetap menempuh jalur litigasi dengan tujuan memberikan keadilan berupa pemutusan pemidanaan sehingga akan mempermudah pada proses perceraian; (5) Kurangnya rasa percaya masyarakat pada aparat penegak hukum yang bertugas sebagai mediator dalam perkara pidana, sehingga masyarakat memiliki anggapan negatif yang melahirkan kecurigaan yang tidak beralasan. ${ }^{32}$

\section{Penanganan Kasus KDRT di Kepolisian Resort Kota Sidoarjo melalui Mediasi Penal}

Jalur litigasi merupakan sarana yang banyak digunakan untuk menyelesaikan tindak pidana, termasuk perkara kekerasan dalam rumah tangga. Undang-Undang Nomor 23 Tahun 2004 tentang Penghapusan Kekerasan Dalam Rumah Tangga hanya tidak memberikan ruang untuk penyelesaian KDRT dengan jalan perdamaian atau kekeluargaan. Menurut Hani Barizatul Baroroh, penyelesaian perkara KDRT dalam system peradilan pidana memiliki beberapa kelamahan, antara lain: (1) para pihak tidak

\footnotetext{
${ }^{30}$ Hani Barizatul Baroroh, "Mediasi penal sebagai alternatif penyelesaian kekerasan dalam rumah tangga (kdrt)," IN RIGHT: Jurnal Agama dan Hak Azazi Manusia 2, no. 1 (24 Maret 2017): 196, http://ejournal.uin-suka.ac.id/syariah/inright/article/view/1238.

${ }^{31}$ Laely Wulandari, "Kebijakan penanganan kekerasan dalam rumah tangga melalui mediasi penal," $L A W$ REFORM 4, no. 1 (23 Oktober 2010): 17, https://doi.org/10.14710/lr.v4i1.312.

32 Satrio Putro Wihanto, Abdul Madjid, dan Bambang Sugiri, "Implementasi mediasi penal dalam penyelesaian kasus kdrt (kekerasan dalam rumah tangga) studi (polresta malang dan polrestabes surabaya)," Kumpulan Jurnal Mahasiswa Fakultas Hukum 1, no. 1 (2014): 12-14, http://hukum.studentjournal.ub.ac.id/index.php/hukum/article/view/482.
} 
diberikan waktu dan kesempatan yang cukup untuk berpartisipasi mengutarakan konsep keadilan perspektif masing-masing; (2) hanya memperhatikan fakta hukum dan mengabaikan faktor emosi. Korban tidak dapat secara tuntas menceritakan derita yang dialaminya; (3) prosedur pemeriksaan kaku, rumit, dan lama. Hal ini cenderung menambah penderitaan korban; (4) biaya yang diperlukan tinggi; (5) penjatuhan hukuman pidana gagal memberikan efek jera kepada pelaku; (6) penjatuhan pidana penjara kepada pelaku, yang mayoritas adalah tumpuan ekonomi keluarga, menyebabkan rusaknya masa depan keluarga dan anak-anak. ${ }^{33}$

Berdasarkan kondisi ini, tidak sedikit kasus tindak pidana KDRT diselesaikan secara damai dengan menerapkan mediasi penal. Beberapa kasus yang diselesaikan di Kepolisian Resort Kota Sidoarjo. Penyelesaian perkara KDRT dengan mediasi didasarkan kepada: (a) Pasal 15 ayat (2) huruf k dan Pasal 16 ayat (1) huruf 1 UndangUndang Nomor 2 Tahun 2002 tentang Kepolisian Negara Republik Indonesia; Surat Kepala Kepolisian Negara Republik Indonesia Nomor Pol: B/3022/XII/200S/SDEOPS tanggal 14 Desember 2009 tentang Penanganan Kasus Melalui Alternatif Dispute Resolution (ADR); (c) Peraturan Mahkamah Agung RI Nomor 2 Tahun 2012 tentang Penyesuaian Batas Tindak Pidana Ringan dan Jumlah Denda dalam KUHP; (d) Peraturan Kepala Kepolisian Negara Republik Indonesia Nomor 7 Tahun 2008 tentang Pedoman Dasar Strategi dan Implementasi Pemolisian Masyarakat dalam Penyelenggaraan Tugas POLRI.

Proses mediasi perkara pidana dilakukan dengan cara menghadirkan para pihak berperkara. Pelaku dan korban dipertemukan secara langsung dibantu oleh anggota kepolisian sebagai mediator. Mediator dalam hal ini adalah seorang penyidik yang menggunakan hak diskresi. Hak diskresi hanya dapat dipergunakan dalam keadaan yang sangat perlu dan mendesak dengan tetap memperhatikan peraturan perundang-undangan yang berlaku. Mediator bertugas membantu merumuskan tujuan dari para pihak berperkara sehingga tercapai kesepakatan. Mediator tidak berhak memaksa para pihak beperkara untuk memilih bentuk penyelesaian. ${ }^{34}$

Tindak pidana KDRT yang masuk di Unit Pelayanan Perempuan dan Anak (PPA) Kepolisian Resort Kota Sidoarjo dari tahun 2015 sampai tahun 2017 mengalami perubahan pada setiap tahunnya, tetapi dalam prakteknya dapat diketahui bahwa penyelesaian perkara KDRT di Polresta Sidoarjo lebih dominan dengan penyelesaian perkara secara non-litigasi menggunakan sarana mediasi penal . Dari 67 kasus tersebut telah terselesaikan dengan jalur non-litigasi yaitu mediasi penal sebanyak 59 kasus yang bila di prosentasekan menjadi $92 \%$ kasus terselesaikan dengan sarana mediasi penal.Sebanyak 4 kasus yang bila diprosentasekan menjadi $4 \%$ terlesesaikan dengan jalur litigasi dan 4 kasus lainnya yang bila diprosentasekan menjadi $4 \%$ masih dalam proses dan belum tercapai penyelesaian. Hal ini selaras dengan dasar pergaulan masyarakat Sidoarjo yang lebih mengedapankan asas kekeluargaan, kekerabatan dan gotong royong.Sehingga membentuk rasa toleransi dan mudah memaafkan dengan mendahulukan kepentingan bersama. ${ }^{35}$.

Contoh kasus KDRT yang terselesaikan dengan Alternatif mediasi penal yaitu pada kasus KDRT dengan Nomor Register Laporan Polisi LPB/194/V/2015/JATIM/RES SDA, tanggal 18 Mei 2015 dengan nama Pelapor Neneng Noorziah dan terlapor Muhammad Hafilludin. Neneng melaporkan suaminya Hafilludin dengan aduan telah

\footnotetext{
${ }^{33}$ Baroroh, "Mediasi penal," 189.

${ }^{34}$ Rohmawati Lailah, Wawancara, (Sidoarjo: 21 Agustus 2017)

${ }^{35}$ Rohmawati Lailah, Wawancara, (Sidoarjo: 17 Mei 2017)
} 
melakukan tindak pidanaKDRT terhadap dirinya yang melakukan kekerasan fisik dengan cara mencengkeram pergelangan tangan korban sehingga korban mengalami luka, adapun pemicuutamanya adalah faktor ekonomi. Yang kemudian oleh penyidik Polresta Sidoarjo dilakukan pengamatan yang menunjukan bahwa kasus tersebut memberikan dampak yang relatif ringan terhadap korban sehingga penyidik Polresta Sidoarjomengupayakan damai diantara para pihak dengan tujuan tidak pecahnya bangunan rumah tangga. Selanjutnyadilakukan proses mediasi didalam sebuah forum dengan menghadirkansaudari Neneng dan saudara Hafiludin untuk dipertemukan secara lansung dan di dampingi oleh penyidik yang sekaligus bertugas sebagai mediator dan selanjutnya para pihak melakukan perundingan, bermusyawarah, dan bernegosiasi dimana mediator sebagai orang ketiga yang bertugas membantu merumuskan permasalahan sehingga tercapai mufakat dan terpecahkan perkara KDRT dengan hasil yang diinginkan serta disepakati para pihak. ${ }^{36}$

Contoh kasus KDRT yang terselesaikan dengan jalan mediasi penal pada tahun 2016, yaitu kasus KDRT dengan Nomor register laporan polisi LPB/43/I/2016/JATIM/RES SDA yang tercatat pada Tanggal 31 Januari 2016 atas nama pelapor NM dan terlapor RP. RP dilaporkan karena telah melakukan kekerasan terhadap NM dengan cara menampar pipi korban. Sehingga terjadi pembengkakan ringan pada pipi korban. Hasil penyidikan menunjukkan bahwa akibat perbuatan pelaku tergolong dalam kategori dampak ringan terhadap korban yang seharusnya masih bisa diperbaiki. Dari pertimbangan tersebut penyidik menyarankan untuk melakukan upaya damai dengan menggunakan medaisi kepada para pihak. Harapannya rumah tangga antara pelaku dengan korban masih dapat diselamatkan. Pertanggung jawaban dibebankan kepada pelaku untuk memperbaiki kerusakan yang telah dilakukan. Kemudian kedua pihak berperkara bersedia untuk melakukan mediasi penal dengan di dampingi oleh penyidik yang bertindak sebagai mediator dalam penyelesaian perkara tersebut sehingga dapat tercapai penyelesaian perkara dengan hasil yang telah disepakati oleh para pihak. ${ }^{37}$

Kepala Unit Pelayanan Perempuan dan Anak (PPA) Polresta Sidoarjo, AKP Rohmawati Lailah, S.H. menyatakan sarana mediasi penal ini sesuai dengan karakteristik masyarakat Sidoarjo yang masih mengutamakan penyelesaian perkara dengan cara damai. Dalam sengketa dalam ranah keluarga, keutuhan keluarga menjadi prioritas budaya masyarakat Sidoarjo yang selalu dijaga. ${ }^{38}$ Mediasi penal dalam penerapannya selain memberikan manfaat yang sangat baik bagi para pihak berperkara juga ditemui kendala dalam pelaksanaannya, antara lain: ${ }^{39}$ a) aparat penegak hukum kesulitan meyakinkan pihak berkerkara untuk menyelesaikan kasus dengan sarana mediasi; b) waktu yang terbatas. Mediasi penal tergabung pada sistem peradilan pidana sehingga terdapat keterbatasan waktu dalam pelaksanaan mediasi terhadap sebuah kasus, meskipun kasus tersebut sangat komplek dan sensitive; c) persiapan dan tindak lanjut yang kurang. Banyaknya penyidik yang bertugas menjadi mediator yang kurang mempersiapkan diri dalam menyelesaikan sebuah kasus, padahal tingkat kompleksitas dan kesensitifan kasus berbeda antara yang kasus yang satu dengan yang lain. Pemahaman mediator yang beranggapan bahwa tugas telah usai seiring dengan terjalinnya kesepakatan dari kedua belah pihak, padahal masih tetap diperlukan pengawasan terhadap pelaksanaan kesepakatan yang telah terjalin; d) kegagalan dalam mempertahankan tujuan awal; Hal

\footnotetext{
${ }^{36}$ Rohmawati Lailah dan Siti Dewi Khotimah (Sidoarjo: 21 Agustus 2017)

${ }^{37}$ Rohmawati Lailah dan Siti Dewi Khotimah (Sidoarjo: 21 Agustus 2017)

${ }^{38}$ Rohmawati Lailah dan Siti Dewi Khotimah (Sidoarjo: 21 Mei 2017)

${ }^{39}$ Rohmawati Lailah dan Siti Dewi Khotimah (Sidoarjo: 21 Mei 2017)
} 
ini kerapkali terjadi karena adanya dominan pada sistem peradilan pidana, sehingga tujuan daripada mediasi penal yang masih tergabung pada sistem tersebut menjadi goyah; e) Akuntabilitas Pelaku.Adanya pemanfaatan dari pelaku pidanayang penggunaan mediasi penal sebagai jalan untuk menghindar dari peradilan pidana penjara.Sehingga setelah tercapai kesepakatan mereka tidak menjalankannya. ${ }^{40}$

\section{Kesimpulan}

Proses penyelesaian perkara kekerasan dalam rumah tangga dengan mediasi penal dilaksanakan oleh penyidik yang ditunjuk oleh Kapolresta Sidoarjo melalui Surat Perintah Tugas yang memerintahkan penyidik sekaligus sebagai mediator dalam penyelesaian perkara KDRT dengan disertai hak diskresi. Tahap penyelesaian perkara KDRT menggunakan mediasi penal diawali dengan mempertemukanpara pihakuntuk bermusyarawah dengan didampingi oleh mediator yang bertugas membantu menyelesaikan perkara, sehingga tercapai penyelesaian perkara dalam bentuk mufakat sesuai dengan keinginan para pihak. Kendala yang terjadi dalam pelaksanaan mediasi penaldiantaranyabelum ada lembaga yang menaungi mediasi penal selain itu, kurangnya rasa kepercayaan masyarakat terhadap aparat penegak hukum yang bertugas sebagai mediator kerapkali menimbulkan kecurigaan yang tidak beralasan, Keterbatasan waktu juga merupakan salah satu kendala yang mempengaruhi pelaksanaan mediasi penal.

\section{Daftar Pustaka}

Abdurrachman, Hamidah. "Perlindungan Hukum Terhadap Korban Kekerasan Dalam Rumah Tangga dalam Putusan Pengadilan Negeri Sebagai Implementasi Hak-Hak Korban.” Jurnal Hukum IUS QUIA IUSTUM 17, no. 3 (2010): 475-91.

Baroroh, Hani Barizatul. "Mediasi penal sebagai alternatif penyelesaian kekerasan dalam rumah tangga (KDRT).” IN RIGHT:Jurnal Agama dan Hak Azazi Manusia 2, no. 1 (2012).

- "Mediasi penal sebagai alternatif penyelesaian kekerasan dalam rumah tangga (kdrt)." IN RIGHT: Jurnal Agama dan Hak Azazi Manusia 2, no. 1 (24 Maret 2017). http://ejournal.uin-suka.ac.id/syariah/inright/article/view/1238.

Fitriani, Ika Kurnia. "Urgensi Pemeriksaan Psikis Pra-Nikah (Studi Pandangan Kepala KUA dan Psikolog Kota Malang).” De Jure: Jurnal Hukum dan Syariah 7, no. 1 (21 Juni 2016): 18. https://doi.org/10.18860/j-fsh.v7i1.3506.

Hajati, Sri, Agus Sekarmadji, dan Sri Winarsih. "Model Penyelesaian Sengketa Pertanahan Melalui Mediasi Dalam Mewujudkan Penyelesaian Yang Efisiensi Dan Berkepastian Hukum.” Jurnal Dinamika Hukum 14, no. 1 (31 Januari 2014): 36-48. https://doi.org/10.20884/1.jdh.2014.14.1.275.

Helmi, Muhammad Ishar. "Pengadilan Khusus KDRT 'Implementasi Gagasan Sistem Peradilan Pidana Terpadu Penanganan Kasus-Kasus Kekerasan Terhadap Perempuan (SPPT-PKKTP)." JURNAL CITA HUKUM 2, no. 2 (12 Januari 2014). https://doi.org/10.15408/jch.v1i2.1471.

Irfani, Amalia. "Peran Forum Mediasi Dalam Meminimalisir Konflik Di Kalimantan Barat." Al-Hikmah 9, no. 2 (1 Desember 2015). https://doi.org/10.24260/alhikmah.v9i2.327.

\footnotetext{
${ }^{40}$ Rohmawati Lailah dan Siti Dewi Khotimah (Sidoarjo: 21 Mei 2017)
} 
Jamal, Ridwan. "Resolusi Konflik Perkawinan Melalui Mediasi Dalam Perkara Perceraian Di Pengadilan Agama Manado.” Jurnal Ilmiah Al-Syir'ah 15, no. 2 (31 Desember 2017). https://doi.org/10.30984/as.v15i2.478.

Komnas Perempuan. "Kekerasan terhadap Perempuan Meluas: Negara Urgen Hadir Hentikan Kekerasan terhadap Perempuan di Ranah Domestik, Komunitas dan Negara: catatan kekerasan terhadap perempuan tahun 2015." Jakarta: Komnas Perempuan, 2016.

. "Labirin Kekerasan terhadap Perempuan: Dari Gang Rape hingga Femicide, Alarm bagi Negara untuk Bertindak Tepat: catatan kekerasan terhadap perempuan tahun 2016." Jakarta: Komnas Perempuan, 2017.

. "Tergerusnya ruang aman perempuan dalam pusaran politik populisme: catatan kekerasan terhadap perempuan tahun 2017.” Jakarta: Komnas Perempuan, 2018.

Makarao, M. Taufik. "Pengkajian hukum tentang penerapan restorative justice dalam penyelesaian tindak pidana yang dilakukan oleh anak-anak." Jakarta: BPHN Kementerian Hukum dan Hak Asasi Manusia Republik Indonesia, 2013.

Nadir. "Politik hukum pidana dalam upaya penghapusan kekerasan rumah tangga sebagai wujud pengakuan dan perlindungan ham." Al-Ahkam: Jurnal Pemikiran Hukum Islam 5, no. 1 (2010).

Nevey Verida Ariani. "Alternatif penyelesaian sengketa bisnis di luar pengadilan." Rechtsvinding: Media Pembinaan Hukum Nasional 7, no. 1 (2012).

Pratiwi, Yulia. "Peranan advokad dalam menerapkan mediasi penal sebagai alternatif penyelesaian perkara pidana: studi penerapan mediasi penal di wiayah surakarta." Skripsi, Universitas Jenderal Soedirman, 2013.

Prayitno, Kuat Puji. "Restorative justice untuk tindak pidana di Indonesia: [ersektif yuridis filosofis dalam penegakan hukum in concreto." Dinamika Hukum 12, no. 3 (2012).

Putri, Nella Sumika, dan I. Tajudin. "Penyelesaian tindak pidana lalu lintas melalui pendekatan restorative justice sebagai dasar penghentian penyidikan dan perwujudan asas keadilan dalam penjatuhan putusan." Padjadjaran Journal of Law 2, no. 1 (27 April 2015). http://jurnal.unpad.ac.id/pjih/article/view/7178.

Rahmawati, Erik Sabti. "Implikasi Mediasi Bagi Para Pihak yang Berperkara di Pengadilan Agama Malang." De Jure: Jurnal Hukum dan Syariah 8, no. 1 (Juni 2016): 1. https://doi.org/10.18860/j-fsh.v8i1.3725.

Ramadani, Mery, dan Fitri Yuliani. "Kekerasan dalam rumah tangga (KDRT) sebagai salah satu isu kesehatan masyarakat secara global." Jurnal Kesehatan Masyarakat $\begin{array}{lllll}\text { Andalas } & 9 \text {, } & & \end{array}$ http://jurnal.fkm.unand.ac.id/index.php/jkma/article/view/191.

Savitri, Nita. "Kekerasan dalam rumah tangga (KDRT) dan budaya hukum: suatu tinjauan antropologis." Jurnal Harmoni Sosial 2, no. 1 (2007).

Sudaryono, M. Iksan, dan Kuswardani. "Model penyelesaian secara alternatif dalam peradilan pidana (studi khusus terhadap model penyelesaian perkara pidana oleh lembaga kepolisian).” Jurnal Penelitian Humaniora 13, no. 1 (2012).

Suhariyanto, Budi. "Restorative justice dalam pemidanaan korporasi pelaku korupsi demi optimalisasi pengembalian keuangan negara." Jurnal RechtsVinding: Media Pembinaan Hukum Nasional 5, no. 3 (2016).

Sukoco, Bambang. "Pendekatan Restoratif Justice Sebagai Upaya Penyelesaian Cybercrime Dengan Pelaku Anak (Studi Kasus Penyelesaian Tindak Pidana Anak 
Usia Sekolah)." Law and Justice 1, no. 1 (31 Oktober 2016): 54-64-64. https://doi.org/10.23917/laj.v1i1.2859.

Sumiadi, Laila M. Rasyid, dan Romi Asmara. "Restorative justice hakim terhadap anak yang berkonflik dengan hukum di pengadilan negeri lhokseumawe." Mimbar Hukum 29, no. 1 (2017).

Tedjosaputro, Liliana, dan Krismiyarsi Krismiyarsi. "Kebijakan Penanggulangan Kejahatan Melalui Mediasi Penal Sebagai Alternatif Penyelesaian Tindak Pidana Kdrt." Jurnal Kriminologi Indonesia 8, no. 1 (25 Juli 2012). http://journal.ui.ac.id/index.php/jki/article/view/1081.

Undang-Undang Republik Indonesia Nomor 23 Tahun 2004 Tentang Penghapusan Kekerasan Dalam Rumah Tangga, Pub. L. No. 95, 1 (2004).

Widiarta, I. Ketut, Prija Djatmika, dan Bambang Sugiri. "Penyelesaian perkara kdrt melalui mediasi penal pada tingkat penyidikan di polres kapuas." Kumpulan Jurnal Mahasiswa Fakultas Hukum 1, no. 1 (2014). http://hukum.studentjournal.ub.ac.id/index.php/hukum/article/view/482.

Widihastuti, Setiati, Sri Hartini, dan Eny Kusdarini. "Mediasi dalam penyelesaian sengketa kesehatan di jogja mediation center.” Socio: Jurnal Ilmu-Ilmu Sosial 14, no. 1 (2017).

Wihanto, Satrio Putro, Abdul Madjid, dan Bambang Sugiri. "Implementasi mediasi penal dalam penyelesaian kasus kdrt (kekerasan dalam rumah tangga) studi (polresta malang dan polrestabes surabaya)." Kumpulan Jurnal Mahasiswa Fakultas Hukum 1, no. 1 (2014).

Wulandari, Laely. "Kebijakan penanganan kekerasan dalam rumah tangga melalui mediasi penal." LAW REFORM 4, no. 1 (23 Oktober 2010): 1. https://doi.org/10.14710/lr.v4i1.312. 